\title{
Integrated Reporting Framework Application: A European Case Study in the Financial Sector
}

\author{
Adriana TIRON-TUDOR \\ Babes-Bolyai University, Faculty of Economics and Business Administration, Cluj-Napoca, \\ Romania \\ Octavian JULA \\ Babes-Bolyai University, Faculty of Economics and Business Administration, Cluj-Napoca, \\ Romania \\ Diana Lavinia MARTIN \\ Babes-Bolyai University, Faculty of Economics and Business Administration, Cluj-Napoca, \\ Romania \\ Gianluca ZANELLATO \\ Babes-Bolyai University, Faculty of Economics and Business Administration, Cluj-Napoca, \\ Romania
}

\begin{abstract}
The ongoing academic debate about Integrated Reporting (IR) outlines that a particular interest shall be accorded to the financial sector organizations. Furthermore, previous researches in the field of an IR demonstrates the need of further research in the developing the actual knowledge of the advancement and implementation of IR and how are companies applying the guiding principles given by the framework. Therefore, this research aims to analyze to what extent European Union financial sector organization are following the IIRF guidance. Using a sample of 140 annual reports, a manual content analysis has been employed to identify the compliance evolution of financial sector organizations towards the IIRF contents elements, for the period 2013-2017. Results reveals the attention given by financial organisations, toward the "Organisational Overview", "Risks \& Opportunities" and "Business Model" content elements of IR. While the categories that remain unforeseen are "Performance \& Outcomes", "Other Elements" but the problematical category is "Future Outlook" with the lowest disclosure degree.
\end{abstract}

Keywords: reporting, integrated approach, integrated reporting, IIRF.

\section{Introduction}

In the context of corporate reporting, voluntary disclosure can be considered as a manner to influence stakeholder's perception (Milgrom, 1986) as well as a manner to maintain "...legitimacy of a business organisation within a business and investment climate characterised by an increasing interest in social and environmental impacts of economic activity" (Brammer\& Pavelin, 2006; p. 1169).

It is the case of financial services organisations which are considered to be extremely relevant as their services are indispensable to societies (WEF, 2013) and as are playing an important role in allocating resources among different sectors of the economy (Jeucken, 2010). Unfortunately, after the 2008 financial crises, there has been a loss of confidence by the civil society toward financial organizations, as they failed to attend the society's development, through their business activity (Krasodomska, 2015). According to Acharya \& Richardson (2009), the financial market's proper functioning requires information, reporting and disclosure toward markets operators, regulators and supervisors. Information required for the proper functioning can be provided by financial 
sector organizations through the release of non-financial reports. In this vein, financial sector organizations have been voluntarily embracing the Integrated Reporting (IR) movement, since its very beginning, in 2011. In particular, after the release of the official International Integrated Reporting Framework (IIRF) in 2013, financial organizations have been a constant presence in the official database of the International Integrated Reporting Council. According to Wild \& van Staden (2013), in 2013, 21\% of worldwide IR adopters were belonged to the financial sector. Whilst, according to Lodhia (2015) "banks do not have massive environmental impacts, their social and ethical responsibilities are extensive, especially through their lending practices and therefore, their involvement in integrated reporting is essential" (p. 32).

Considered to be the evolution of the voluntary Sustainability Report (SR) (Mio, 2016), IR “is a concise communication about how an organization's strategy, governance, performance and prospects, in the context of its external environment, lead to the creation of value over the short, medium and long term" (IIRC, 2013; p.7).

The ongoing debate about IR demonstrate the need of further research in the developing the actual knowledge of the advancement and implementation about IR and how are companies applying the guiding principles given by the framework (Cheng et al., 2014). In particular, Dumay et al. (2016) argue that there are not sufficient studies reviewing the practice of IR.

In this perspective, the present paper aims to analyse to what extent European Union (EU) financial sector organization have is following the IIRF guidance since the release of the framework (2013) to the latest available in 2017. We motivate the decision of limiting the present research to EU's financial sector organization, as the EU has been facing its first wave of regulation of non-financial information through the European Directive 2014/95/EU coming into effect from 2017 onwards, therefore an increasing in disclosure levels should be expected. Moreover, the focus on the financial sector is motivated by the significant impact on social development and the environment given by such institutions (Buys \& van Niekerk, 2014).

This paper brings different contributions to the state of the art as it responds to the ongoing debate about the use of the IR, as well as, adding to the actual knowledge of IR issuers an improved list of reporters using the IIRF.

First of all, it outlines the compliance level by European financial sector organization through the employment of a checklist of 31 items for all the content elements required by the IIRF, which can be consider a deeper analysis from a previous similar research at the European level (Sofian \& Dumitru, 2017).As the present contribution investigate a different section of the IR international database, providing a wider picture of financial institutions close to the IR movement.

The research paper unfold as follows: the second section provide a review of the relevant literature about the financial sector organizations need of disclosure, few references about the IR movement and previous studies regarding SR and IR compliance in other fields and into the same sector. The third section presents the theoretical framework under which this study has been developed, fourth section presents the population composition of the study and the methodology employed for the research. Section five presents the results of the analysis and discussions. The final section presents concluding remarks, limitations and future research direction for the present study.

\section{State of the art}

Financial sector organizations represent the largest industry according to market capitalization (Sofian \& Dumitru, 2017), in the same time are relevant organisation as 
these provide important services for the development of societies (Jeucken, 2010; WEF, 2013).

According to Krasodomska (2015) the financial sector unlike others implicates a large and heterogeneous public and after the 2008 crises, due to the loss of confidence by civil society toward similar organizations as they failed to deliver communities growth through their activities. In order to, regain credibility financial sector appeared to embrace the wave of CSR reports with the extent to improve their accountability and the transparency (Lentner et al, 2015). Still, the adoption of corporate reporting has been higher in industrial sectors rather than financial sector (Kolk, 2003).

Acharya \& Richardson (2009), arguing about the causes of the financial crises, consider that the financial market's proper functioning requires information, reporting and disclosure toward markets operators, regulators and supervisors. In this perspective Eccles \&Krusz (2010) outlined the increased number of appearances of the term "nonfinancial information" beginning from 2006 to 2008.

Long before the above-mentioned crises, the academic debate has been focusing on the factors influencing voluntary disclosure by companies (Verrecchia, 1983; Trueman, 1997; Hughes \& Sankar, 1997; and Evans and Sridhar, 2002) and arguing whether the disclosure of information can be manipulated to influence stakeholder's decisions (Milgrom, 1986). Furthermore, scholars have been arguing about the increasing demand of social and environmental information required by stakeholders (Neu et al., 1998), moving the debate about stakeholders' requirements forward as corporate reporting became more complex (de Villiers et al., 2014; Hughen et al., 2014).

In this vein, SR became a useful tool for companies to report toward stakeholder's organizations challenges and issues about relevant aspects of their activities (Buys \& van Niekerk, 2014). Recently, companies have been embracing the IR movement since its beginning, it is considered to be the evolution of the SR (Mio, 2016) the new reporting trend intends to bring together financial and non-financial information of the organizations (Eccles \& Saltzman, 2011). Through a concise report, organizations shall communicate their strategy, governance, performance and outcomes, and how issuers are creating value in the short, medium and long term (IIRC, 2013).

The ongoing debate on the use of the IR, presents some deficiencies as according to Cheng et al. (2014) outlining the concept of IR and issues that have been debated until the time of his writing, he observed the needed of further studies in order to understand the implementation of IR. Additionally, de Villiers et al. (2014) consider being "crucial to continue to closely monitor the state of implementation of integrated reporting to develop a deeper understanding" (p.23).

To this extent, scholars have been studying the compliance of IR adopters in different regions. In particular, Marx \&Mohammadali Haji (2014) performed a compliance study on 40 South African enterprises, ranked by market capitalization, through the use of content analysis; authors developed a checklist based on six categories. Their results demonstrate a heterogeneous situation which varies "from excellent to poor" (Marx \&Mohammadali Haji, 2014; p. 244).

Moreover, Setia et al. (2015) analyzed whether 25 JSE listed organizations were preparing their report in accordance with KING III (2009), which is the first national regulation through which the Johannesburg Stock Exchange made mandatory to the listed companies the adoption of the predecessor of Integrated Reporting beginning in 2010 (Solomon \& Maroun, 2012). Setia et al.' (2015) research has been performed trough the employment of content analysis per two years 2009/2010 and 2011/2012, as these are the years before and after the adoption of the KING III. The results of the research 
demonstrate significantly higher after the adoption of the regulation. In particular, highest increasing had been outlined in the case of organizations with results below average before the adoption of KING III.

Furthermore, a compliance study based on a global sample of 58 companies, participants to the IR Pilot Programme, outlines that at the beginning stage of IR adoption just few organizations were covering more than three principles while the rest was covering two principles out of five (Wild and van Staden, 2013).

In addition, a further research based on the IR Pilot Programme participant as at 2011, with a population of 91 companies from different countries and sectors, RiveraArrubla et al. (2017) outlines that the highest disclosure results have been obtained by organizations from South-Africa, Brazil and Netherlands (countries with relevant governance codes and in particular South-Africa with KING III),worst results belong to companies coming from countries with a long tradition of financial information disclosure like USA and UK.

Moreover, Kilic\&Kuzey (2018) identified the level of adoption of IR in Turkey. In this case, the research, based on a sample of the 100 biggest organization, by market capitalization, from the BIST (Istanbul Stock Exchange), outlines the current situation of corporate reporting in Turkey based on the content elements of the IIRF. The outcome of the study demonstrates, that in Turkey, companies are merely disclosing specific risks of their activities whilst are not reporting specific risks of their activity. Additionally, authors outline the positive association between the IR disclosure with the SR (Kilic\&Kuzey, 2018).

Pistoni et al. (2018) investigated the IR quality of 116 integrated issued by 58 international organisations, included in the "Getting Started" section of the IR international database, over 2 years, 2013-2014. Results from their research outline a low quality in IR and the quality does not significantly increase over the analysed period. Their findings are consistent with previous studies and, albeit, their research focuses on the first two years since the apparition of the IIRF, authors consider the "whole application of the IR model is still far away" (Pistoni et al., 2018; p.504).

Despite the relevance of the financial services, previously outlined, contributions about financial sector organizations reporting have hardly been observed. However, financial institutions are not new to the realm of non-financial corporate reporting. Examples are available in the literature that confirms the financial sector organisations interest for Corporate Social Responsibility and SR.

In this vein, Araya et al. (2014) with an exploratory analysis of the European cooperative banks, analysed a sample of 8 European organizations demonstrating the low level of adoption by cooperative banks, outlining the Spanish-s financial organisations commitment toward the sustainability and in particular, authors, highlight the higher level of social information provided by cooperative banks. Whilst, Matuszak\&Rozanska (2017) analysed the ongoing status of CSR reporting in the case of Polish banks listed on the Warsaw Stock Exchange. Findings demonstrate the preference of the analysed sample for annual reports rather than CSR report. Also, Polish banks disclose more information regarding community, environment, labour practices, while are not disclosing enough info about human rights and fight against corruption (Matuszak\&Rozanska, 2017).

In the case of IR, Lodhia (2015) investigated the adoption process of an Australian corporate owned bank suggesting the need of organizational structures and operations "to be e aligned with strategic goals and designed to enable integrated thinking" (p. 34).

Still, few researches have been dedicated to the financial services company's compliance toward the IIRF or SR. 
Accordingly, a compliance study has been performed Buys \& van Niekerk (2014) on the IR of 40 JSE organization involved in the financial service industry, for the period 2012-2013, analysing whether or not these organizations are applying Global Reporting Initiative (GRI) guidelines. Results of the study express a successful implementation of GRI "as a means of demonstrating maximum transparency and accountability" (p. 113).

Moreover, a longitudinal study about the information disclosure in the case of Singapore's banking, food \& beverages and hotel industries for a period of ten years, outlines the low disclosure level on social information for the analysed banking organizations (Tsang, 1998).

According to the author best knowledge, today research on the use of the IIRF in the case of financial sector organizations have been implemented also in the case of the European Union. As, Sofian \& Dumitru (2017), investigated a sample of 8 European financial organizations related to the year 2015, grounding their research on a checklist of seven categories. Their results demonstrate a different level of disclosure. Companies member of the IIRC pilot programme obtain higher results, as according to their checklist Generali ranked first followed by other members of the pilot programme (Sofian \& Dumitru, 2017).

Another contribution concerning a European financial organisation, demonstrate that the at least in the case disclosure of sustainability information is more likely to be found in the SR, rather than the IR. But, according to the authors of the mentioned research the analysed reports are done in respect to the recommendation of the guidelines settlers (Tiron-Tudor et. al, 2019)

\section{Theoretical framework}

Even though, IR has been conceived, according to the IIRF, to improve the quality of information to financial capital providers (IIRC, 2013), the same framework aims to "benefit all stakeholders interested in an organisation's ability to create value over time..." (p. 4). To date the IR's adoption, remain on a voluntary base, but in the case of financial sector organisation the voluntary disclosure gains a crucial importance as according to Branco \& Rodriguez (2006) financial sector organisations have "a high visibility and are expected to exhibit greater concern to improve the corporate image as this is susceptible of influencing sales and may be considered more likely to make social responsibility disclosure" (p. 237).

In particular, in the case of these organisations the existence of a social contract (Guthrie, 2006) between the organization and the environment in which it operates is essential; therefore, this sets the ground for the existence of legitimacy theory.

"Legitimacy provides a linkage between the organizational and societal level of analysis. Legitimacy and social norms and values constrain the actions taken by individual organizations" (Pfeffer \& Dowling, 1975; p. 131).

According to Linblom (1994), legitimacy is "a status, which exists when an entities value system is congruent with the value system of the larger social system of which the entity is a part. When a disparity, actual or potential, exists between the two value systems, there is a threat to the entities' legitimacy".

In this context, due to the financial cries is possible to state that these entities are trying to recover from the image damage suffered, through the employment of such report in order to modify the perception of their stakeholder as proposed by Lindblom (1994). The four strategies proposed by the author with which companies can gain legitimacy in their environment; at first organizations should try to keep up to date information regarding performances and activities for its stakeholder; then, influencing 
their perceptions without changing their behaviour. As a third move, companies can try to manipulate stakeholder's perception moving their attention toward favourable facts; fourth organizations can try to shape and influence the external expectations of its performance (Guthrie et al., 2006).

An example of the above mentioned strategy is provided by case study performed by Casonato et al. (2019) in which authors outline the intention of an Australian financial institution to regain trust and legitimacy through the adoption of different reports, including IR, after a scandal in 2004.

\section{Methodology}

Sample Composition

The sample required for the present research has been gathered from the IIRC database under the section of IR Reporters, which presents an exhaustive situation of reporters. The European financial sector attracted the interest of Sofian \& Dumitru (2017), which proposed a compliance analysis based on both the guiding principles and the content elements mentioned in the IIRF.For a sample composed by eight listed financial organisations coming from the IIRC examples database, they performed a content analysis of the IRs of 2015.

Our study, sets its ground on the same sector, but we propose a different approach in order toobtain the final sample of organizations, with the extent to have a wider picture of the actual disclosure provided by European financial sector organisations. In order to have a comprehensive overview about the IR issuers in the financial sector we divided the sample gathering in two steps: a first row of organization has been added based on the official documents, publicly available on the internet, given by the IIRC named "IIRC Pilot Programme Business Network" for 2013 and 2014 and through the official web sites the presence of further IR has been checked. Nonetheless, organizations from the "IR Reporters" section of the official database of the IIRC, have been analysed in order to establish the sector of belongings through the employment of the international database: Thomson Reuters EIKON.

To this extent, the results of our two steps sample collection lead to a sample composed by 7 organisations member of the Pilot Programme and 21 companies that embraced the IR journey even though they were not member of the IIRC Programme.

Moreover, a manual analysis of the official websites of the organizations has been carried out with the extent to detect whether organizations were issuing IR, Annual Report, Annual Review before being included in the IIRC lists. In both steps of sample gathering, organization belonging to "Banking", "Insurance", "Financial Services" have been considered part of the financial sector, as done by other scholars (Sofian \& Dumitru, 2017; Manes-Rossi et al., 2018). IR, Annual Report, Annual Review are further downloaded from the official sites of the organization for the recognized available years.

\section{Analysis}

Manual Content analysis has been employed to identify the compliance evolution of financial sector organizations towards the IIRF. It is "a research technique for making replicable and valid inferences from texts (or other meaningful matter) to the contexts of their use" (Krippendorff, 1980; p. 18), research method uses a set of procedures to make valid inferences from text (Weber, 1990), respectively codifying text into various categories and can be used where a great amount of qualitative information needs to be analysed (Linsley\& Shrives, 2006). This method has already been used in disclosure studies (Greiling et al., 2015; Setia et al., 2015; Venturelli, 2017; Dumitru, 2017). 
More specifically, the present study grounds its checklist (see Appendix 1) on the framework proposed by Zhou et al. (2017), as it covers all the content foreseen by the framework proposed by the IIRC. In addition to the framework proposed by Zhou et al. (2017) this research outlines whether organization are mentioning or not the application of the IIRF in their reports, this with the extent to strength the actual knowledge of IR reporters and, also, the number of pages in order to measure how the "conciseness" principle is understood by the analyzed organizations.

In order to assess the disclosure level of the reports, grounded on the checklist mentioned above, a dichotomous coding system has been employed, where the presence of the element has been recognized through the attribution of (1) and (0) when the absence of the element have been recognized (Greiling et al., 2015; Setia et al., 2015; Guse et al., 2016; Venturelli, 2017; Manes-Rossi et al., 2018).

In this vein, the International Integrated Reporting Compliance Index (IIRF_CI) has been composed as follows:

$$
I I R F C I=\sum_{j=1}^{m} \frac{\overline{I I R F C I_{J}}}{m}
$$

Where, $\sum_{j=1}^{m} \frac{C I_{j}}{m}$ is the sum of the content emerged from the analyzed reports according to the Zhou et al. (2017) categories, $m$ is the maximum number of categories (8) and $\overline{I I R F C I}_{j}$ is the average per category obtained as follows:

$$
\overline{I I R F C I_{j}}=\sum_{i=1}^{n_{j}} \frac{d_{i j}}{n_{j}}
$$

Where, $\sum_{i=1}^{n_{j}} \frac{d_{i j}}{n_{j}}$ is the average of the elements per each content in each category analysed (e.g. "Business Overview" has five elements).

Further, all the 140reports have been analysed, the data were collected, with the extent to purse the objective of the present investigation, by three researchers than the results were discussed and have been given.

\section{Results \& discussions}

The sample of reporters is composed as presented in table 1, being composed by 140 analysed reports for the period investigated.

Table 1: Sample Presentation

\begin{tabular}{lcccccc}
\hline \multicolumn{1}{c}{ Country } & $\mathbf{2 0 1 3}$ & $\mathbf{2 0 1 4}$ & $\mathbf{2 0 1 5}$ & $\mathbf{2 0 1 6}$ & $\mathbf{2 0 1 7}$ & Total \\
\hline Austria & 1 & 1 & 1 & 1 & 1 & 5 \\
France & 2 & 2 & 2 & 2 & 1 & 9 \\
Germany & 1 & 1 & 1 & 1 & 1 & 5 \\
Italy & 6 & 6 & 6 & 6 & 5 & 29 \\
Netherlands & 8 & 8 & 8 & 8 & 8 & 40 \\
Spain & 3 & 3 & 3 & 3 & 2 & 14 \\
Sweden & 2 & 2 & 3 & 3 & 3 & 13 \\
UK & 5 & 5 & 5 & 5 & 5 & 25 \\
\hline Total & $\mathbf{2 8}$ & $\mathbf{2 8}$ & $\mathbf{2 9}$ & $\mathbf{2 9}$ & $\mathbf{2 6}$ & $\mathbf{1 4 0}$ \\
\hline
\end{tabular}

Source: Authors' own processing.

Concerning the composition of the sample, the initial number of organisations which are presenting IR for 2013 remains the same in 2014 and to them are added in 2015 another Swedish company, being the same until 2016. But, in 20173 companies 
have abandoned the journey of IR and did not published any other comparable report. According to our analysis, the number of IIRF adopters has been increasing constantly until 2016.

Moreover, the analysis aimed to outline the mention of adoption of the IIRF in their reports (IR; Annual Report, Annual Review) by financial sector organisations (table 2).

Table 2: IIRF Mentions

\begin{tabular}{lccccc}
\hline \multicolumn{1}{c}{ Country } & $\mathbf{2 0 1 3}$ & $\mathbf{2 0 1 4}$ & $\mathbf{2 0 1 5}$ & $\mathbf{2 0 1 6}$ & $\mathbf{2 0 1 7}$ \\
\hline Austria & 0 & 0 & 1 & 0 & 0 \\
France & 0 & 0 & 1 & 1 & 1 \\
Germany & 0 & 0 & 0 & 0 & 0 \\
Italy & 3 & 4 & 4 & 6 & 4 \\
Netherlands & 1 & 3 & 4 & 6 & 6 \\
Spain & 0 & 0 & 0 & 1 & 1 \\
Sweden & 1 & 1 & 3 & 2 & 2 \\
UK & 0 & 0 & 0 & 0 & 0 \\
\hline N. Of IIRF Mentions & $\mathbf{5}$ & $\mathbf{8}$ & $\mathbf{1 3}$ & $\mathbf{1 6}$ & $\mathbf{1 4}$ \\
\hline
\end{tabular}

PICBE | 234

Source: Authors' own processing.

By delineating the number of IIRF adopters, the present contribution demonstrates a significant different number of organisations which are embracing the IR journey in comparison to the list proposed by the official database (examples.integratedreporting.org) under the section "Recognized Reports", which is significantly higher than the number of organisations presented in the database.

Table 3 presents the average report's length evolution

Table 3: Report's Length

\begin{tabular}{cccccc}
\hline Year & 2013 & 2014 & 2015 & 2016 & 2017 \\
\hline Average & 303 & 274 & 267 & 270 & 216 \\
\hline
\end{tabular}

Source: Authors' own processing.

Our conciseness analysis presents a positive trend toward the recommended length of 204 pages (Enslin et al. 2015; KPMG; 2015). We agree with Motecalvo et al. (2018) about the adoption of IR reducing the length of the reports. On the other hand, we confirm the idea of Stubbs \& Higgings (2018) that consider reports still too long and complex. Considerably similar to PwC (2016) 200 pages are still too long.

Moving toward the core of the present research, the compliance analysis demonstrates an increasing observance toward the framework. The following table presents the compliance results as an average on the analysed categories as well as the results obtained by each category.

Table 4: Compliance Average Results

\begin{tabular}{|c|c|c|c|c|c|c|c|}
\hline Elements & & 2013 & 2014 & 2015 & 2016 & 2017 & Average \\
\hline Organisational Overview & & 0.71 & 0.81 & 0.87 & 0.86 & 0.83 & 0.82 \\
\hline Governance & & 0.46 & 0.64 & 0.73 & 0.75 & 0.67 & 0.65 \\
\hline Risks \& Opportunities & & 0.63 & 0.64 & 0.69 & 0.84 & 0.87 & 0.73 \\
\hline Strategy and Resource Allocation & & 0.34 & 0.51 & 0.56 & 0.72 & 0.64 & 0.55 \\
\hline Business Model & & 0.29 & 0.38 & 0.55 & 0.75 & 0.77 & 0.55 \\
\hline Performance \& Outcomes & & 0.23 & 0.43 & 0.55 & 0.57 & 0.53 & 0.46 \\
\hline Future Outlook & & 0.35 & 0.40 & 0.47 & 0.52 & 0.44 & 0.44 \\
\hline Other Elements & & 0.38 & 0.58 & 0.53 & 0.46 & 0.50 & 0.49 \\
\hline IIRF_CI & 0.42 & 0.55 & & 0.62 & 0.62 & 0.68 & 0.67 \\
\hline
\end{tabular}

Source: Authors' own processing. 
As presented in table 4, there is a constant increasing toward the IIRF_CI until 2017 where there is a difference of 0,01 . The below exposed chart presents the average level of compliance (columns) as well as the score evolution per each category (lines).

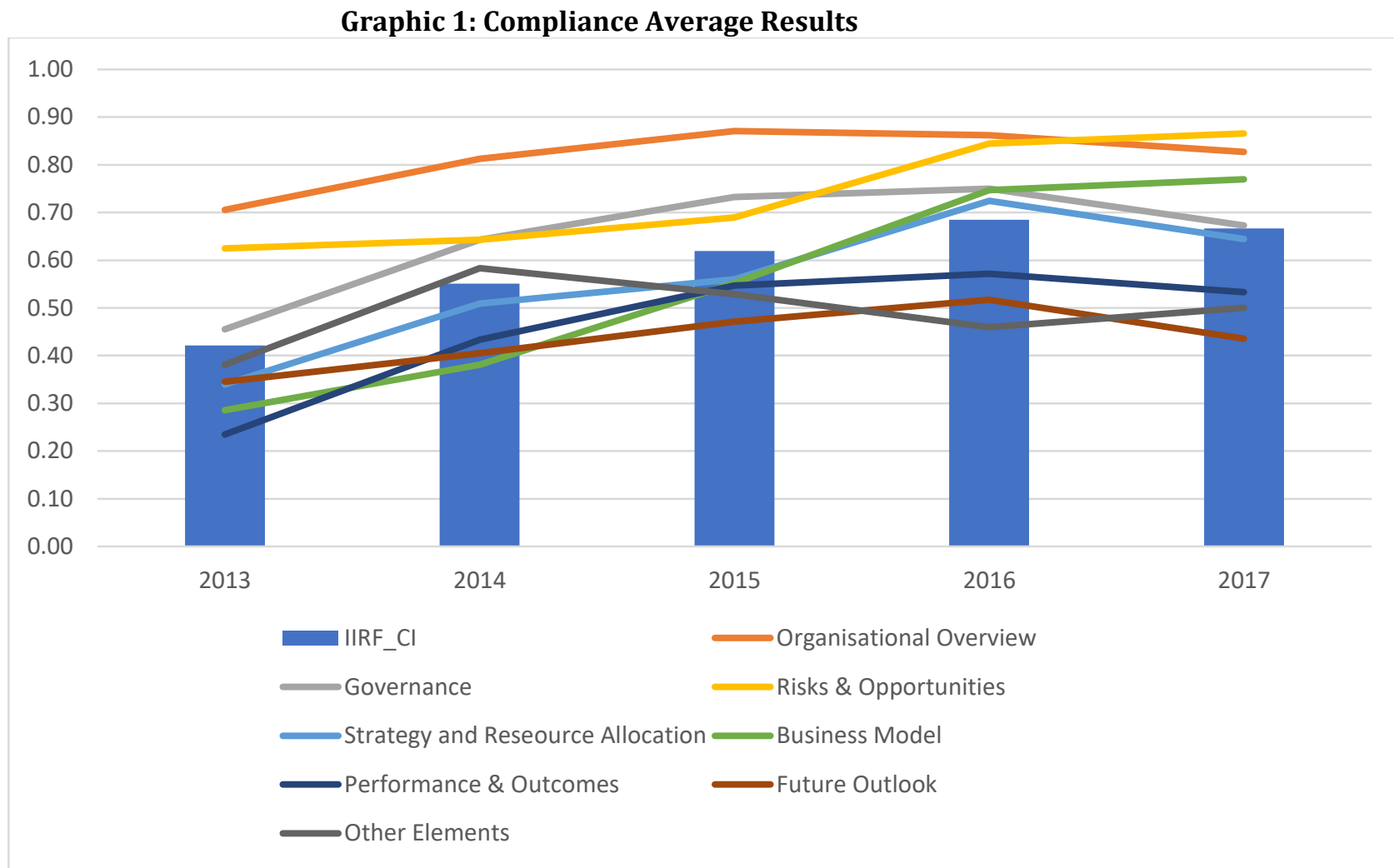

Source: Authors' own processing.

The evidences provided both, in table 3 and chart 1 demonstrate particular attention, given by financial organisations, toward the "Organisational Overview", "Risks \& Opportunities" and "Business Model". While the categories that remain unforeseen are "Performance \& Outcomes", "Other Elements" but the problematical category is "Future Outlook".

Beginning from 2013, we confirm previous research findings where on a worldwide sample, for the first-year adoption of the IIRF, scholars suggests that companies adopting IR are still in its infancy, as these organizations address two or three contents (Wild \& van Staden, 2013). As, in our case the average compliance index, for the first year, 2013, is below 0,5.

Moreover, in comparison to the results obtained by Marx \& Mohammadali Haji (2014) our findings for the same year, demonstrate a similar level of disclosure for the Organizational Overview, Governance and Future Outlook contents. While, for the remaining contents we observed a significant lower level of compliance, due to the mandatory corporate governance KING III in the JSE, where the sample has been gathered. To this extent, Rivera-Arubla et al. (2017) confirm the higher compliance rate from South-African companies.

While, Setia et al. (2015) outline an increasing rate of compliance from the year before the adoption of KING III as "disclosures are under increased scrutiny via regulated disclosure requirements" (p.417).

Still, the above-mentioned examples, present a major issue as they are organisation headquartered in South-Africa, where through the adoption of the stock 
exchange regulation KING III IR become mandatory for listed companies and other organisations.

Comparing our results with other disclosure studies focused on the European Union area for the year 2016, we obtain lower results in comparison to Manes-Rossi et al (2018). As, our findings are lower in similar categories but higher on the Business Model content. Also, we obtained higher results than Venturelli et al. (2017) for the Italian section of the sample analysed, in the case of Business Model.

Moreover, our results are similar for the year 2013 and 2014 are similar to Pistoni et. al (2018) in particular in the case of the future outlook category, financial sector organisations were not able to disclose sufficient elements on their future, which has also been founded in a research on the Turkish stock exchange (Kılıç and Kuzey, 2018).

According to the compliance results, is possible to consider that European financial institutions are acting in compliance with social norms and consolidate values to meet stakeholder's expectation and (re)gain legitimacy (Setia et al., 2015).

Noteworthy to mention are the favourite categories of disclosure by financial organisations, "Organisational Overview", "Risk \& Opportunities" and "Business Model" as these three content demonstrate to the reader why the organisations exist, how is creating value to the society and what risks can affect the activity of the organisation as well as opportunities for future developments. Therefore, through a higher attention given by these organisations toward these three particular content we consider that financial sector entities are trying to strength their legitimacy toward stakeholder which has seen a decreasing by the civil society (Krasodomska, 2015).

\section{Conclusion}

Financial sector needs of non-financial information (Acharya \& Richardson, 2009), the need to regain trustworthiness (Krasodomska, 2015) and the EU Directive on nonfinancial information for organizations of public interest are drivers of the increasing rate of IR adopters and compliance toward the framework, as organizations are seeking and trying to keep approval from their communities in order to meet their requirement of information.

Our study, demonstrate a deep understanding of some relevant categories proving a great quantity of information where others are still at an embryonal phase. Therefore, the path toward more complete IR is still at the beginning. Once organisations will fully understand the IIRF there will be better and more concise reports.

The present study, add to the state of the art a small contribution in the still open debates about how organisations are using the IIRF (Cheng et al, 2014; de Villiers et al., 2014; Dumay, 2016). Furthermore, our investigation brings a deeper investigation on the European financial sector from the one proposed by Sofian \& Dumitru (2017). To this extent, our research presents a practical implication demonstrating to the IIRC how many organisations are mentioning the use of the IIRF in their report.

One of the limitations of our study relies in the scoring approach and in the merely compliance analysis which does not take into consideration other factors driver of disclosure.

To this extent, further studies are recommended to understand the quality of information disclosed in the IR, as well as studies investigating reason and factors influencing the level of disclosure. 


\section{Appendix 1}

\begin{tabular}{cc} 
& Reporting boundary \\
Organizational overview and operating context & Mission and value \\
& Business Overview \\
Operational Context & Summary Statistics \\
\hline Governance & Governance Structure \\
& Governance Strategy \\
& Remuneration and Performance \\
Risks Opportunities & Governance and Others \\
\hline \multirow{2}{*}{ Risks } \\
\hline
\end{tabular}

PICBE $\mid 237$

Strategic Objectives

Strategy and Resource Allocation

Links Between strategy and Other Elements

Competitive Advantage

Stakeholder Consultations

Business Model Description

Business Model

Links between Business Model and Others

Stakeholder Depenceniesc

KPIs against Strategy

Explanation of KPIs

Stakeholder Relationship

Performance and Outcomes

Past, Current, and Future Performance

Financial Implications of Other Capitals

Supply Chain Performance

The quality of Quantitative Indicators

\begin{tabular}{cc}
\hline Future Outlook & $\begin{array}{c}\text { Anticipated Changes } \\
\text { Potential Changes } \\
\text { Estimates }\end{array}$ \\
\hline Other Elements & Conciseness and Link \\
& Materiality Determination Process \\
& The Board Sign-Off \\
\hline
\end{tabular}




\section{References}

Abeysekera, I. (2013). A template for integrated reporting. Journal of Intellectual Capital, 14(2), 227-245.

Adams, S., \& Simnett, R. (2011). Integrated Reporting: An opportunity for Australia's notfor-profit sector. Australian Accounting Review, 21(3), 292-301.

Adams, S., \& Simnett, R. (2011). Integrated Reporting: An opportunity for Australia's not- PICBE | 238 for-profit sector. Australian Accounting Review, 21(3), 292-301.

Alvani, M. (2008). Public management (32th ed.). Tehran: Ney publication.

Araya, H. M. B., Mas, E. S., \& Garrido, F. P. (2014). Sustainability reporting in European cooperative banks: An exploratory analysis. In REVESCO. Revista de Estudios Cooperativos (Vol. 115, pp. 30-56). Universidad Complutense de Madrid.

Bartocci, L., \& Picciaia, F. (2013). Towards integrated reporting in the public sector. In Integrated Reporting (pp. 191-204). Springer, Cham.

Buys, P., \& Van Niekerk, E. (2014). The South African financial services industry's integrated reporting compliance with the global reporting initiative framework.

Castelo Branco, M., \& Lima Rodrigues, L. (2006). Communication of corporate social responsibility by Portuguese banks: A legitimacy theory perspective. Corporate Communications: An International Journal, 11(3), 232-248.

Del Baldo, M. (2015). Is it time for integrated reporting in small and medium-sized enterprises? Reflections on an Italian experience. In Corporate Social Responsibility and Governance (pp. 183-209). Springer, Cham.

Dumay, J., Bernardi, C., Guthrie, J., \& Demartini, P. (2016, September). Integrated reporting: a structured literature review. In Accounting Forum (Vol. 40, No. 3, pp. 166-185). Elsevier.

Eccles, R. G., \& Krzus, M. P. (2010). One report: Integrated reporting for a sustainable strategy. John Wiley \& Sons.

EU Commission. Directive 2014/95/EU of the European Parliament and the Council of 22 October 2014 amending Directive 2013/34/EU as Regards Disclosure of NonFinancial and Diversity Information by Certain large Undertakings and Groups; EU Commission: Brussels, Belgium, 2014; pp. 1-9.

Fortis, Z., Maon, F., Frooman, J., \& Reiner, G. (2016). Unknown knowns and known unknowns: Framing the role of organizational learning in corporate social responsibility development. International Journal of Management Reviews, 20(2), 277-300.

Gherardi, S., \& Nicolini, D. (2002). Learning in a constellation of interconnected. Journal of Management Studies, 39(4), 419-436.

Greiling, D., Traxler, A. A., \& Stötzer, S. (2015). Sustainability reporting in the Austrian, German and Swiss public sector. International Journal of Public Sector Management, 28(4/5), 404-428

Guthrie, J., Manes-Rossi, F., \&Levy Orelli, R. (2017). Integrated reporting and integrated thinking in Italian public sector organizations. Meditari Accounting Research, 25(4), 553-573.

Incollingo, A., \& Bianchi, M. (2016). The connectivity of information in integrated reporting. Empirical evidence from international context. Financial Reporting.

Integrated Reporting. International Integrated Reporting Framework. 2013. Available online: www. integratedreporting.org/resource/international-ir-framework/ (accessed on 23 January 2018). 
Jensen, J. C., \& Berg, N. (2012). Determinants of traditional sustainability reporting versus integrated reporting. An institutionalist approach. Business Strategy and the Environment, 21(5), 299-316.

Jeucken, M. (2010). Sustainable finance and banking: The financial sector and the future of the planet. Routledge.

Katsikas, E., Rossi, F. M., \& Orelli, R. L. (2016). Towards Integrated Reporting: Accounting Change in the Public Sector. Springer

Kılıç, M., \& Kuzey, C. (2018). Assessing current company reports according to the IIRC integrated reporting framework. Meditari Accountancy Research.

Krasodomska, J. (2015). CSR disclosures in the banking industry. Empirical evidence from Poland. Social Responsibility Journal, 11(3), 406-423.

Krippendorff K. (1980), Content analysis: An introduction to its methodology, The Sage CommText Series, Sage, Beverly Hills, CA.

Laughlin, R.C. (1991), Environmental disturbances and organizational transitions and transformations: Some alternative models. Organization Studies, 12(2), 209-232.

Linsley, P. M., \& Shrives, P. J. (2006). Risk reporting: A study of risk disclosures in the annual reports of UK companies. The British Accounting Review, 38(4), 387-404.

Lodhia, S. (2015). Exploring the transition to integrated reporting through a practice lens: an Australian customer owned bank perspective. Journal of Business Ethics, 129(3), 585-598.

Kuabara, P. S.S., \& Takahashi, A. R.W. (2017). Organizational learning, practices of diversity, and ceremonialism: a study proposal in the multinational's context. Revista de Administracao Mackenzie, 18(5), 169-201.

Marx, B., \& Mohammadali-Haji, A. (2014). Emerging trends in reporting: an analysis of integrated reporting practices by South African top 40 listed companies. Journal of Economic and Financial Sciences, 7(1), 231-250.

Matuszak, Ł., \& Różańska, E. (2017). CSR Disclosures in Listed Banks-Current State and Future Perspective. Prace Naukowe Uniwersytetu Ekonomicznego we Wrocławiu, (478 Finanse i rachunkowość na rzecz zrównoważonego rozwoju-edukacja, etyka, innowacje. Finanse), 311-323.

Mayo, A. (1994). The power of learning: a guide to gaining competitive advantage, IPD, House, London

Mio, C. (Ed.). (2016). Integrated Reporting: A New Accounting Disclosure. Springer.

Neu, D., Warsame, H., \& Pedwell, K. (1998). Managing public impressions: Environmental disclosures in annual reportsa. Accounting, organizations and society, 23(3), 265282.

Rivera-Arrubla, Y. A., Zorio-Grima, A., \& García-Benau, M. A. (2017). Integrated reports: disclosure level and explanatory factors. Social Responsibility Journal, 13(1), 155176.

Saadat, V., \& Saadat, Z. (2016). Organizational learning as a key role of organizational success. Social and Behavioral Sciences, 230(2016), 219-225.

Setia, N., Abhayawansa, S., Joshi, M., \& Huynh, A. V. (2015). Integrated reporting in South Africa: some initial evidence. Sustainability Accounting, Management and Policy Journal, 6(3), 397-424.

Siebehuner, B., \& Arnold, M. (2007). Organizational learning to manage sustainable development. Business Strategy and Environment 16, 339-353.

Sofian, I., \& Dumitru, M. (2017). The Compliance of the Integrated Reports Issued by European Financial Companies with the International Integrated Reporting Framework. Sustainability, 9(8), 1319. 
Stubbs, W., \& Higgins, C. (2014). Integrated reporting and internal mechanisms of change. Accounting, Auditing \& Accountability Journal, 27(7), 1068-1089.

Tsang, E. W. (1998). A longitudinal study of corporate social reporting in Singapore: The case of the banking, food and beverages and hotel industries. Accounting, Auditing \& Accountability Journal, 11(5), 624-635.

Unerman, J. (2000). Methodological issues-Reflections on quantification in corporate social reporting content analysis. Accounting, Auditing \& Accountability Journal, 13(5), 667-681.

Venturelli, A., Caputo, F., Cosma, S., Leopizzi, R., \& Pizzi, S. (2017). Directive 2014/95/EU: Are Italian Companies Already Compliant?. Sustainability, 9(8), 1385

Weber, R. P. (1990). Basic content analysis (No. 49). Sage.

Wild, S., \& van Staden, C. (2013, July). Integrated reporting: initial analysis of early reporters-an institutional theory approach. In 7th Asia Pacific Interdisciplinary Accounting Research Conference (pp. 26-28). 